\title{
JEA
}

\section{PENGARUH PEMBAYARAN UTANG PASCA IPO TERHADAP PERTUMBUHAN PERUSAHAAN}

\author{
Ana Inelia ${ }^{1}$, Nurzi Sebrina ${ }^{2}$ \\ ${ }^{1}$ Alumni Jurusan Akuntansi Fakultas Ekonomi, Universitas Negeri Padang \\ ${ }^{2}$ Jurusan Akuntansi Fakultas Ekonomi, Universitas Negeri Padang \\ *Korespondensi: anainelia80@gmail.com
}

\begin{abstract}
This study to examine the effect of post-IPO debt payments on firm growth. Research is a causative research, the population are the companies which listed on the Indonesia Stock Exchange in 2013-2017, there are 64 companies as research samples that obtained from www.idx.co.id, method used is multiple linear regression analysis. The results showed that DER has a significant effect, which means that a high level of leverage can be proven to increase the motivation of companies to use IPO funds to pay debts and interest spread has no significant effect. It means that a high level of interest spread cannot explain firm motivation using IPO funds to pay down debt. high retiring has no significant effect, which means that a high debt payments cannot prove an increase in firm growth and the low retiring has no significant effect, meaning that low debt payments cannot explain the increase in firm growth. POSTIPO which has no significant effect, that means that post-IPO conditions cannot prove a better long-term operating performance and POSTIPO *HR has no significant effect, which means the reaction conditions post-IPO with a high level of debt payments cannot prove that long-term operating performance length is better.
\end{abstract}

Keywords: Debt Payment, IPO, firm growth

\section{How to cite (APA $6^{\text {th }}$ style)}

Inelia, A \& Sebrina, N. (2019). Pengaruh Pembayaran Utang Pasca IPO terhadap Pertumbuhan Perusahaan. Jurnal Eksplorasi Akuntansi, 1(4), Seri C, 1881-1895.

\section{PENDAHULUAN}

Persaingan dunia bisnis tidak terlepas dari pengaruh kondisi ekonomi, sosial, politik serta teknologi. Kondisi-kondisi ini menyebabkan ketidakpastian dalam lingkungan persaingan. Persaingan yang terus meningkat mengakibatkan perusahaan untuk melakukan inovasi dan strategi bisnis agar memiliki kinerja yang baik dan mampu tetap bertahan di tengah persaingan. Perusahan didirikan tentu untuk terus berkembang dan tumbuh dalam kurung waktu yang tidak ditentukan (Suwardjono, 2005).

Nilai perusahaan dapat mencerminkan kinerja perusahaan yang dapat mempengaruhi kepercayaan stakeholder terhadap perusahaan, nilai perusahaan dapat digambarkan dengan pertumbuhan perusahaan. Pertumbuhan (growth) adalah seberapa jauh perusahaan menempatkan diri dalam sistem ekonomi secara keseluruhan atau sistem ekonomi untuk industri yang sama (Machfoedz, 2007). Pada umumnya, perusahaan yang tingkat pertumbuhannya baik dan 
pertumbuhan perusahaanya cepat memperoleh pemantapan posisi yang baik dalam era persaingan, peningkatan penjualan yang sangat signifikan dan mengalami peningkatan pangsa pasar.Kasmir (2010) menyatakan pertumbuhan perusahaan menggambarkan kemampuan perusahaan dalam mempertahankan posisi ekonomi ditengah pertumbuhan ekonomi dan kemampuan bertahan dalam persaingan yang ketat di sektornya.

Pertumbuhan perusahaan sangat diharapkan oleh pihak internal dan eksternal perusahaan karena dapat menggambarkan perkembangan perusahaan yang baik kedepannya. Persaingan antar industri sangat mempengaruhi kondisi pertumbuhan perusahaan, sehingga perusahaan dihadapkan pada keputusan penting dalam bidang keuangan yakni pendanaan. Perusahaan yang bertumbuh, yakni perusahaan yang menginvestasikan kembali labanya, sebaliknya perusahaan yang tidak bertumbuh yaitu perusahaan yang tidak menahan laba untuk reinvestasi (Keown, 2008). Pertumbuhan perusahaan dapat dilihat dari tingkat penjualan karena semakin meningkat penjualan maka pangsa pasar juga akan meningkat, dengan hal ini membuktikan bahwa perusahaan mampu menempatkan posisi yang kuat pada era persaingan. Pertumbuhan juga dapat dilihat dari peningkatan pertumbuhan lapangan kerja, semakin tinggi tingkat pertumbuhan lapangan kerja semakin besar pula hasil operasional yang akan dihasilkan sesuai dengan hasil Takahashi dan Yamada, (2015). Penelitian Fan, (2018) membuktikan tingkat pertumbuhan lapangan kerja signifikan dapat mengambarkan pertumbuhan perusahaan.

Pertumbuhan perusahaan yang tinggi mengakibatkan kebutuhan dana yang meningkat. Menurut Firnanti (2011) pertumbuhan perusahaan dapat menumbuhkan kepercayaan kreditur dan kesedian pemberian pinjaman utang jangka panjang. Pertumbuhan yang cepat membutuhkan dana yang besar, dalam hal ini perusahaan dituntut untuk dapat mengendalikan operasi dengan penekanan pada pengendalian biaya (Susanto, 1997: 185-187). Atmaja (2013) mengatakan bahwa manajer keuangan perusahaan harus mampu mempertimbangkan komposisi pendanaan dari utang yang digunakan oleh perusahaan. Perusahaan yang banyak melakukan pembiayaan dengan utang tidaklah sehat. Perusahaan yang tingkat rasio utang (leverage) tinggi dapat menghambat investasi dan pertumbuhan perusahaan karena menciptakan potensi insentif investasi rendah (Hart dan Moore,1995; Myers, 1997). Tingkat utang yang tinggi dapat menghambat pertumbuhan perusahaan bahkan dapat memberikan dampak negatif terhadap nilai perusahaan sehingga menurunnya kepercayaan stakeholder untuk memberikan pendanaan (Natali, 2013). Secara logika, perusahaan harus dapat menghasilkan keuntungan untuk dapat menutupi kewajiban (utang), keadaan ini dapat menghambat perusahaan untuk melakukan pengembangan usaha, laba yang dihasilkan digunakan untuk pembayaran utang yang jatuh tempo pada waktu tertentu.

Menurut Subramayam (2005), semakin besar tingkat proporsi utang pada struktur modal perusahaan, semakin tinggi beban tetap dan komitmen pengembalian yang ditimbulkan. Kemungkinan perusahaan tidak mampu membayar bunga dan pokok pinjaman saat jatuh tempo dan kemungkinan perusahaan gagal bayar pun meningkat. Perusahaan yang rasio utang (leverage) semakin besar menggambarkan bahwa struktur modal yang digunakan perusahaan lebih banyak memanfaatkan utang dari pada dengan modal sendiri yang dapat meningkatkan risiko perusahaan menghadapi kebangkrutan. Keadaan ini mengakibatkan perusahaan mengutamakan kewajiban membayar utang dibandingkan dengan kepentingan perusahaan lainnya.

Berdasarkan uraian diatas, tingginya tingkat utang dan semakin besarnya rasio utang dapat menghambat pertumbuhan perusahaan. Perusahaan tidak akan mampu menghadapi 
perkembangan persaingan yang ketat, untuk terus tumbuh perusahaan harus memiliki strategi bisnis dan inovasi baru seperti pengembangan usaha. Pengembangan usaha membutuhkan dana yang sangat besar, mengakibatkan perusahaan sangat membutuhkan laba yang dihasilkan perusahaan untuk memenuhi kebutuhan pendanaan. Perusahaan yang memiliki tingkat leverage tinggi tentu menggunakan laba yang dihasilkan perusahaan sebagian besar untuk menutupi kewajiban dari pada pengembangan usaha. Pada kondisi ini tingkat penjualan perusahaan akan menurun tentunya tingkat laba yang dihasilkan juga ikut menurun, risiko perusahaan akan mengalami kebangkrutan meningkat.

Initial public offering secara konvensional dipandang sebagai peluang bagi perusahaan untuk meningkatkan modal ekuitas untuk peluang pertumbuhan (Lowry, 2003). Menurut Almilia (2003), perusahaan memutuskan menjadi perusahaan publik disebabkan perusahaan berada pada tahap pertumbuhan, sehingga membutuhkan dana. Perusahaan tertutup (private) tidak dapat memanfaatkan pasar ekuitas publik, mempersulit perusahaan untuk melakukan deleverage, aspek negatif dari leverage yang tinggi hal ini seharusnya lebih jelas oleh perusahaan. Initial public offering merupakan salah satu alternatif pendanaan melalui peningkatan ekuitas perusahaan, dengan cara perusahaan menawarkan saham perdana kepada publik.

Alternatif pendanaan bentuk lain atau dengan penerbitan surat-surat utang, maupun pendanaan bersifat pernyataan dalam bentuk saham. Pendanaan melalui mekanisme pernyertaan umumnya dilakukan dengan menjual saham perusahaan kepada masyarakat atau yang sering dikenal dengan initial public offering atau penawaran umum, serta memenuhi semua persyaratan yang ditetapkan Bapepam LK (Martalena dan Malinda, 2011). Penawaran umum perdana (IPO) memberikan peluang penting bagi perusahan swasta tertutup (private) untuk menyeimbangkan struktur modal (Pagano et al., 1998). Secara khusus, perusahaan dapat mengurangi masalah utang yang terlalu tinggi melalui pembayaran utang dengan menggunakan hasil IPO (Pengda,2018). Perusahaan yang melakukan IPO dengan motivasi hasil IPO digunakan untuk pembayaran utang (Busaba et al., 2001; Dunbar dan Foerster, 2008).

Sehubungan dengan motivasi untuk pembayaran utang, bahwa kurangnya peluang investasi dan cenderung menerbitkan saham, perusahaan cenderung menggunakan hasil IPO untuk membayar utang (Amor dan Kooli,2017). Sejumlah besar perusahaan telah menunjukkan bahwa mereka telah menggunakan hasil IPO untuk membayar utang, 42\% perusahaan dari sample penelitian Busaba et al. (2001) dan 31\% dari penelitian Dubar dan Foster (2008). Menurut Luciana (2003) faktor faktor yang mempengaruhi perusahaan melakukan penawaran umum adalah status survivor dengan melakukan penawaran umum perusahaan akan memperoleh pendanaan baru untuk aktivitas perusahaan.

Tabel 1

Perusahaan yang IPO dan Delisting di BEI tahun 2014-2018

\begin{tabular}{ccc}
\hline Tahun & $\begin{array}{c}\text { Perusahaaan } \\
\text { IPO }\end{array}$ & $\begin{array}{c}\text { Perusahaan } \\
\text { Delisting }\end{array}$ \\
\hline 2015 & 24 & 4 \\
\hline 2016 & 16 & 1 \\
\hline $\mathbf{2 0 1 7}$ & $\mathbf{3 7}$ & $\mathbf{1 8}$ \\
\hline 2018 & 1 & 0 \\
\hline
\end{tabular}

Sumber:www.sahamok.com 
Tabel diatas mengambarkan jumlah perusahaan yang melakukan IPO lima tahun terakhir. Pada tabel tersebut perusahaan yang melakukan IPO sudah melihatkan peningkatan yang signifikan pada tahun tahun akhir dibandingkan dengan perusahaan yang delisting ini menggambarkan IPO memberi kesempatan bertumbuh bagi perusahaan.

\section{REVIU LITERATUR DAN HIPOTESIS Theory of Constraints (TOC)}

Teori ini diperkenalkan dengan buku yang berjudul The Goal: A process of Ongoing Improvement, oleh Goldratt dan Cox tahun 2004. Teori ini berisi kumpulan pengetahuan yang menghambat atau membatasi perusahaan dalam mencapai tujuan. Utang yang tinggi dapat menghambat pertumbuhan perusahaan Hart dan Moore, 1995; Myers, 1997). Tingkat utang yang tinggi mengakibatkan laba yang dihasilkan perusahaan untuk menutupi utang, sehingga perusahaan tidak memiliki dana yang cukup untuk melakukan pengembangan usaha atau ekspansi bisnis sehingga perusahaan akan kalah saing didalam dunia bisnis. Kondisi diatas dapat mengakibatkan penurunan tingkat penjualan perusahaan. Menurut Natali (2013) memiliki utang yang berlebih berdampak pada penilaian perusahaan. Perusahaan yang memiliki kewajiban yang tinggi membuat Stakeholder tidak nemiliki keyakinan yang kuat untuk tetap memberikan pendanaan pada perusahaan sehingga perusahaan berada keadaan yang sulit dan berisiko bangkrut.

\section{Pertumbuhan Perusahaan}

Perusahaan didirikan tentu untuk terus berkembang dan tumbuh dalam kurung waktu yang tidak ditentukan (Suwardjono, 2005). Pertumbuhan (growth) adalah seberapa jauh perusahaan menempatkan diri dalam sistem ekonomi secara keseluruhan atau sistem ekonomi untuk industri yang sama (Machfoedz, 2007). Menurut Helfert (1997) pertumbuhan (growth) merupakan dampak dari aktivitas pendanaan arus kas terhadap operasional perusahaan yang disebabkan oleh pertumbuhan atau penurunan volume usaha.

\section{Kebijakan Pendanaan \\ Pecking Order Theory}

Pecking Order Theory adalah teori yang mendasari keputusan pendanaan perusahaan. Perusahaan mempunyai skenario dalam melakukan kebijakan pendanaan. Skenario sumber pendanaan perusahaan, yaitu pendanaan dari dalam perusahaan atau pendanaan internal, jika pendanaan eksternal diperlukan maka perusahaan akan memilih utang dengan risiko yang rendah hingga utang dengan risiko lebih tinggi. Teori ini menyatakan bahwa perusahaan akan memilih pendanaan dari utang terlebih dahulu dari pada menerbitkan saham (Sulindawati et al., 2017). Teori ini menjelaskan perusahaan akan memilih mendanai investasinya berdasarkan suatu risiko. Menurut Sujoko dan Soebiantoro, (2007) manajemen akan berhati hati dalam melakukan keputusan pendanaan dengan melakukan peminjaman, karena tingkat utang yang tinggi akan menimbulkan risiko financial distress.

\section{Initial Public Offering (IPO)}

Penawaran umum (IPO) atau sering juga disebut Go Public adalah kegiatan penawaran saham atau efek lainnya yang dilakukan oleh emiten (perusahaan yang akan go public) untuk menjual 
saham atau efek kepada masyarakat berdasarkan tata cara yang diatur oleh UU Pasar Modal dan peraturan pelaksanaanya (Martalena dan Malinda, 2011).

\section{Pengembangan Hipotesis}

Kasmir (2010) menyatakan pertumbuhan perusahaan menggambarkan bagaimana perusahaan memposisikan diri pada dunia bisnis, dengan semakin maju teknologi maka dunia bisnis semakin cepat berubah. Pertumbuhan perusahaan juga dilihat bagaimana perusahaan dapat memenuhi kebutuhan pasar hal ini dapat mempengaruhi penilaian semua pihak (stakeholder) terhadap perusahaan. Perusahaan dapat tetap tumbuh, berkembang, dan bersaing harus memiliki strategi dan inovasi. pertumbuhan perusahaan memerlukan pendanaan yang besar. Perusahaan yang tertutup akan menggunakan utang untuk menutupi pendanaan pengembangan usaha yang besar. Menurut Firnanti (2011) perusahaan yang memiliki tingkat pertumbuhan yang baik akan mendapat kepercayaan yang tinggi dari kreditur untuk mendapatkan pinjaman. Perusahaan harus bijak dalam menggunakan utang dan mampu mempertimbangkan komposisi pendanaan dari utang (Atmaja, 2013).

\section{METODE PENELITIAN}

\section{Jenis Penelitian}

Penelitian ini termasuk penelitian kausal komparatif. Penelitian kausal komparatif merupakan tipe penelitian yang karakteristik masalahnya berupa hubungan antara dua variabel atau lebih yang berubah sebab akibat. Penelitian ini bertujuan menjelaskan pengaruh variabel bebas (tingkat pembayaran) terhadap variabel terikat yaitu pertumbuhan perusahaan dengan menambahkan variabel kontrol ROA, market to book ratio.

\section{Populasi, Sampel, dan Teknik pengambilan sampel}

Dalam penelitian ini yang menjadi populasi adalah seluruh perusahaan yang IPO dari tahun 2013-2017 sebanyak 65 perusahaan.Penelitian ini membatasi sample dengan memperhatikan perusahaan-perusahaan yang tujuan IPO dinyatakan dalam prospektus dan bunga rata rata tertimbang untuk tahun sebelum IPO tersedia dan perusahaan dengan hutang di Bank sebelum IPO.

\section{Jenis data Sumber Data}

Jenis data yang digunakan pada penelitian ini adalah data dokumenter yaitu data data penelitian yang berupa laporan-laporan yang dimiliki perusahaan yang terdaftar di Bursa Efek Indonesia pada tahun 2013-2017.Sumber data penelitian ini adalah sumber data sekunder.

\section{Instrumen Variabel Penelitian Variabel Dependen}

Variabel terikat adalah variabel yang menjadi perhatian utamadalam sebuah pengamatan. Variabel dependen pada penelitian ini sesuai dengan hipotesis. Hipotesi pertama menggunakan repay (tingkat pembayaran) sebagai variabel dependen. Hipotesis kedua menggunakan rasio pertumbuhan penjualan dan rasio pertumbuhan lapangan kerja sebagai variabel dependen. Hipotesis ketiga menggunakan OCF_TA (operating cash flow to total asset) sebagi variabel dependen. 


\section{Variabel Independen}

Pada hipotesis pertama penelitian ini melihat kecenderungan perusahaan menggunakan hasil IPO untuk membayar utang dengan variabel independennya leverage dan spread bunga. Hipotesis kedua pada penelitian ini melihat kecenderungan perusahaan membayar utang dari dana IPO untuk meningkatkanpertumbuhan bisnis dengan variabel independen hight-retiring dan lowretiring. Hipotesis ketiga penelitian ini melihat pembayaran utang dapat mempengaruhi kinerja operasi jangka panjang dengan variabel independen POSTIPO dan POSTIPO*High-Retiring.

\section{HASIL DAN PEMBAHASAN \\ Uji Asumsi Klasik \\ Uji Normalitas Residual}

Dari Gambar 2 dan 3 dapat dilihat bahwa residual data hipotesis 1 dan hipotesi 3 terdistribusi normal dimana hipotesis 1 dan hipotesis 3 nilai probabilitasnya $>\alpha(0,05)$ yaitu, $0,052476>0,05$. dan $0,081990>0,05$, lihat pada lampiran

\section{Uji Heterokedastisitas}

Menurut Wing (2009), jika probabilitas Chi-Square dari Obs $* R$-squared $>\alpha$ maka tidak terdapat gejala heterokedastisitas. Berdasarkan Tabel 4.15 diatas, probabilitas Chi-Square dari $\mathrm{Obs}^{*} * R$ squared adalah 0.4413 dan 0.5048 . Berarti tidak ada gejala heterokedastisitas karena $0.4413>$ 0,05 dan $0.5048>0,05$. lihat pada lampiran

\section{Uji Multikolinearitas}

Uji multikolinieritas hipotesis pertama menggunakan VIF (Variance Inflation Factors).Hasil uji multikolinieritas, dapat dilihat pada tabel kolom Centered VIF. Nilai VIF untuk variabel DER adalah 1.037225, nilai VIF variabel SB adalah 1.081097, nilai VIF variabel ROA adalah 1.041533 dan nilai VIF variabel MTB adalah 1.052513. Karena nilai VIF dari keempat variabel tidak ada yang lebih besar dari 10 maka dapat dikatakan tidak terjadi multikolinieritas pada keempat variabel bebas tersebut.

Uji multikolinieritas hipotesis ketiga menggunakan VIF (Variance Inflation Factors).Hasil uji multikolinieritas, dapat dilihat pada tabel kolom Centered VIF. Nilai VIF untuk variabel POSTIPO adalah 1.020534, nilai VIF variabel POSTIPO*HR adalah1.019382, nilai VIF variabel ROA adalah 1.024088 dan nilai VIF variabel MTB adalah 1.053410. Karena nilai VIF dari keempat variabel tidak ada yang lebih besar dari 10 maka dapat dikatakan tidak terjadi multikolinieritas pada keempat variabel bebas tersebut.

\section{Uji Autokorelasi}

Penelitian ini menggunakan metode Brusch-Godfrey atau LM (Lagrange Multiplier) Test. Jika nilai Prob. F hitung lebih besar dari tingkat alpha 0.05 (5\%) maka H0 diterima yang artinya tidak terjadi autokorelasi. Sebaliknya, apabila nilai Prob. F hitung lebih kecil dari 0.05 maka dapat disimpulkan terjadi autokorelasi. Berikut adalah tabel hasil uji autokorelasi. Tabel 4.14, menunjukan hipotesis 1 nilai probabilitasnya sebesar 0.2358 dan hipotesis 3 nilai probabilitasnya sebesar 0.7172. Nilai Prob. F hitung dalam penelitian ini lebih besar dari tingkat alpha 0.05 (5\%) sehingga dapat disimpulkan berdasarkan uji hipotesis, H0 diterima yang artinya tidak terjadi autokorelasi. 
Semakin tinggi tingkat leverage dan spread bunga maka semakin memotivasi perusahaan menggunakan hasil IPO untuk membayar utang.

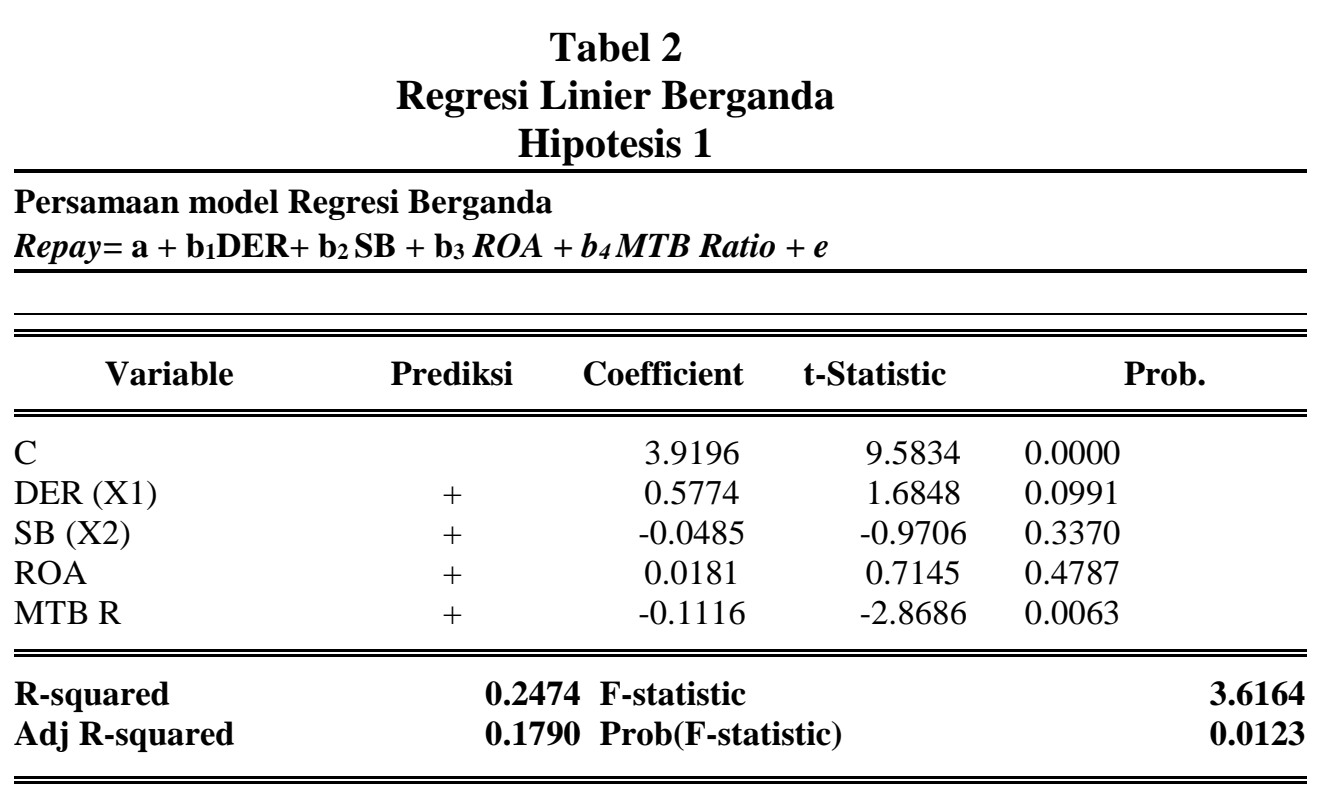

Note : Repay adalah tingkat pembayaran, DER adalah Debt Equity Ratio,Spread Bunga adalah selisih bunga perusahaan dan bunga bank Indonesia SGR adalah Sales Growth Ratio, EGR adalah Employment Growth Ratio, HR dan LR adalah High-Retiring dan LowRetiring, OCF_TA adalah operating cash flow, POSTIPO adalah variabel dummy memberi nilai 1 untuk periode amatan setelah IPO dan 0 utuk sebelum IPO, a adalah konstanta, $\mathrm{b}_{\mathrm{X}}$ adalah koefesien regresi setiap variabel bebas, dan e adalah Standard error

Berdasarkan tabel 2, besaran pengaruh tinggi tingkat utang dan spread bunga terhadap Repay (tingkat pembayaran) yang diwakili oleh koefisien regresi DER dan spread bunga. Dimana berdasarkan Tabel 2 diketahui koefisien regresi DER adalah sebesar 0.5774 dan Spread bunga sebesar -0.0485. Hal ini berarti adanya pengaruh DER terhadap repay sebesar 0.5774 atau $57.7 \%$ dan pengaruh spread bunga terhadap repay sebesar -0.0485 atau $-4.8 \%$. Hasil Adj R-square sebesar 0.1790, yang berarti seluruh variabel bebas berpengaruh terhadap repay sebesar 0.1790 atau 18

\section{Semakin Tinggi Tingkat Pembayaran Utang Setelah IPO maka Kinerja Operasi Jangka Panjang akan Lebih Baik}

Berdasarkan tabel 3, besaran pengaruh tinggi tingkat pembayaran utang maka kinerja operasi yang diwakili oleh koefisien regresi POSTIPO dan POSTIPO*HR. Dimana berdasarkan Tabel 3 diketahui koefisien regresi POSTIPO adalah sebesar -0.0057 dan POSTIPO*HR sebesar -0.0369. $\mathrm{Hal}$ ini berarti adanya pengaruh POSTIPO dan POSTIPO*HR terhadap kinerja operasi sebesar 0.0057 atau $-0.6 \%$ dan -0.0369 atau $-0.37 \%$. Hasil Adj R-square sebesar 0.1403 , yang berarti seluruh variabel bebas berpengaruh terhadap kinerja operasi sebesar 0.1403 atau $14 \%$. 
Tabel 3

\section{Regresi Linier Berganda}

Hipotesis 3

\begin{tabular}{|c|c|c|c|c|}
\hline \multirow{2}{*}{\multicolumn{5}{|c|}{$\begin{array}{l}\text { Persamaan model Regresi Berganda } \\
\mathrm{OCF}_{-} \mathrm{TA}=\mathrm{a}+\mathrm{b}_{1} \mathrm{POSTIPO}_{+} b_{2} P O S T I P O * H R \mathrm{~b}_{3} R O A+b_{4} M T B \text { Ratio }+e\end{array}$}} \\
\hline & & & & \\
\hline Variable & Coefficient & Prediksi & t-Statistic & Prob. \\
\hline $\mathrm{C}$ & 0.0079 & & 0.1300 & 0.8970 \\
\hline POSTIPO (X1) & -0.0057 & + & -0.0998 & 0.9208 \\
\hline POSTIPO*HR (X2) & -0.0369 & + & -1.2076 & 0.2319 \\
\hline ROA & 0.0084 & + & 3.4467 & 0.0010 \\
\hline MTB & -0.0014 & + & -0.4498 & 0.6545 \\
\hline $\begin{array}{l}\text { R-squared } \\
\text { Adjusted R-squared } \\
\end{array}$ & \multicolumn{2}{|c|}{ 0.1940F-statistic } & 0.1403Prob(F-statistic) & $\begin{array}{l}3.6112 \\
0.0105\end{array}$ \\
\hline \multicolumn{5}{|c|}{$\begin{array}{l}\text { Note : Repay adalah tingkat pembayaran, DER adalah Debt EquityRatio,Spread Bunga adalah } \\
\text { selisih bunga perusahaan dan bunga bank Indonesia SGR adalah Sales Growth Ratio, EGR } \\
\text { adalah Employment Growth Ratio, HR dan LR adalah High-Retiring dan Low-Retiring, } \\
\text { OCF_TA adalah operating cash flow, POSTIPO adalah variabel dummy memberi nilai } 1 \text { untuk } \\
\text { periode amatan setelah IPO dan } 0 \text { utuk sebelum IPO, a adalah konstanta, bx adalah koefesien } \\
\text { regresi setiap variabel bebas, dan e adalah Standard error }\end{array}$} \\
\hline
\end{tabular}

\section{Semakin Tinggi Tingkat Penggunaan Dana IPO Untuk Pembayaran Utang Maka Semakin Tinggi Pertumbuhan Perusahaan}

\section{Tabel 4 \\ Regresi panel \\ Hipotesis 2}

\begin{tabular}{|c|c|c|c|c|c|}
\hline \multicolumn{6}{|c|}{$\begin{array}{l}\text { Persamaan model Regresi Panel } \\
\mathrm{SGR}=\mathrm{a}+\mathrm{b}_{1} H R_{+} b_{2} L R+\mathrm{b}_{3} R O A+b_{4} M T B \text { Ratio }+e\end{array}$} \\
\hline Variable & Prediksi & Coefficient & t-Statistic & Prob. & \\
\hline $\mathrm{C}$ & & -0.5225 & -0.5011 & 0.8876 & \\
\hline HR (X1) & + & 0.6820 & 0.1838 & 0.8545 & \\
\hline LR (X2) & + & 0.2629 & 0.0711 & 0.9434 & \\
\hline ROA & + & -0.0092 & -0.3059 & 0.7602 & \\
\hline MTB & + & 0.1869 & 3.4926 & 0.0007 & \\
\hline R-squared & \multirow{2}{*}{\multicolumn{3}{|c|}{$\begin{array}{l}\text { 0.0987 F-statistic } \\
\text { 0.0694 } \\
\text { Prob(F-statistic) }\end{array}$}} & & 3.3711 \\
\hline Adj R-squared & & & & & 0.0117 \\
\hline
\end{tabular}

Note : Repay adalah tingkat pembayaran, DER adalah Debt Equity Ratio,Spread Bunga adalah selisih bunga perusahaan dan bunga bank Indonesia SGR adalah Sales Growth Ratio, EGR adalah Employment Growth Ratio, HR dan LR adalah High-Retiring dan Low-Retiring, 
OCF_TA adalah operating cash flow, POSTIPO adalah variabel dummy memberi nilai 1 untuk periode amatan setelah IPO dan 0 utuk sebelum IPO, a adalah konstanta, $\mathrm{b}_{\mathrm{X}}$ adalah koefesien regresi setiap variabel bebas, dan e adalah Standard error

Berdasarkan Tabel 4, besaran pengaruh tinggi tingkat penggunaan dana IPO untuk pembayaran utang terhadap semakin tinggi rasio pertumbuhan penjualan (Sales Growth Ratio) yang diwakili oleh koefisien regresi Hight-Retiring dan Low-Retiring. Dimana berdasarkan Tabel 4 diketahui koefisien regresi HR adalah sebesar 0.6820 dan LR sebesar 0.2629 . Hal ini berarti adanya pengaruh HR dan LR terhadap kinerja operasi sebesar 0.6820 atau $68 \%$ dan 0.2629 atau $263 \%$. Hasil Adj R-square sebesar 0.0694, yang berarti seluruh variabel bebas berpengaruh terhadap pertumbuhan penjualan (Sales Growth Ratio) sebesar 0.0694 atau 6.9\%.

\section{Uji Model}

\section{Koefisien Determinasi (Adjusted $\boldsymbol{R}^{2}$ )}

Berdasarkan hasil regresi pada Tabel 4.5 , nilai adjusted $R 2$ yang diperoleh sebesar $18 \%$. Hal ini mengindikasikan bahwa kontribusi variabel independen terhadap variabel dependen pada hipotesis pertama menjadi sebesar $18 \%$ dan sebesar $82 \%$ ditentukan oleh variabel lain yang tidak dianalisis dalam model penelitian ini.Berdasarkan hasil regresi pada Tabel 4.8 nilai adjusted $R 2$ yang diperoleh sebesar 7\%. Hal ini mengindikasikan bahwa kontribusi variabel independen terhadap variabel dependen pada hipotesis kedua menjadi sebesar $7 \%$ dan sebesar 93\% ditentukan oleh variabel lain yang tidak dianalisis dalam model penelitian ini.Berdasarkan hasil regresi pada Tabel 4.6 nilai adjusted $R 2$ yang diperoleh sebesar $14 \%$. Hal ini mengindikasikan bahwa kontribusi variabel independen terhadap variabel dependen pada hipotesis ketiga menjadi sebesar $14 \%$ dan sebesar $86 \%$ ditentukan oleh variabel lain yang tidak dianalisis dalam model penelitian ini.

\section{Uji Statistik F(Simultan)}

Berdasarkan Tabel 4.5 untuk hipotesis pertama diketahui bahwa probabilitas $(F$-statistic $)>0,05$ $=3.6164>0,05$ Hal ini menandakan bahwa model regresi diterima atau model regresi ini menunjukkan tingkatan yang baik (good overall model fit). Berdasarkan Tabel 4.8 untuk hipotesis kedua diketahui bahwa probabilitas $(F$-statistic $)>0,05=3.3711>0,05$. Hal ini menandakan bahwa model regresi panel diterima atau model regresi ini menunjukkan tingkatan yang baik (good overall model fit). Berdasarkan Tabel 4.6 untuk hipotesis ketiga diketahui bahwa probabilitas $(F$-statistic $)>0,05=3.6112>0,05$. Hal ini menandakan bahwa model regresi panel diterima atau model regresi ini menunjukkan tingkatan yang baik (good overall model fit

\section{Uji t-Test (Hipotesis)}

Hipotesis pertama regresi pertama merupakan model persamaan regresi yang digunakan untuk mengestimasi pengaruh tinggi tingkat leveragedan spread bungamaka semakin memotivasi perusahaan menggunakan hasil IPO untuk membayar utang. Pada model regresi pertama, dilakukan estimasi pada pengaruh tinggi tingkat leveragedan spread bungamaka semakin memotivasi perusahaan menggunakan hasil IPO untuk membayar utang yang disimbolkan dengan $\beta_{1}$ DER dan $\beta_{2}$ spread bunga. Berdasarkan Tabel 4.5 diketahui bahwa koefisien $\beta_{1}$ DER bernilai positif yaitu 0.5774 , dengan t-hitung 1.6848 , dan signifikan pada $\alpha 5 \%$. Hal ini berarti 
DER berpengaruh signifikan positif terhadap repaysebab nilai signifikansi $<\alpha 10 \%$, yaitu 0.0991 $<10 \%$ serta, t-hitung < t-tabel yaitu, 1.6878>1.6730 dan koefesien $\beta_{2}$ spread bunga negatifyaitu 0.4085 , dengan t-hitung -0.9706 , dan signifikan pada $\alpha 5 \%$. Hal ini berarti SB tidak berpengaruh signifikan positif terhadap repaysebab nilai signifikansi $>\alpha 5 \%$, yaitu $0.3370>5 \%$ serta, t-hitung $<$ t-tabel yaitu, $-0.9706<2.004$

Hipotesis kedua merupakan model persamaan regresi yang digunakan untuk mengestimasi pengaruh pengaruh tinggi tingkat penggunaan dana IPO untuk pembayaran utang maka semakin tinggi pertumbuhan perusahaandisimbolkan dengan $\beta_{1} \mathrm{HR}$ dan $\beta_{2} \mathrm{LR}$. Berdasarkan Tabel 4.8 diketahui bahwa koefisien $\beta_{1}$ HR bernilai positif yaitu 0.6820 , dengan t-hitung 0.1838 , dan signifikan pada $\alpha 5 \%$. Hal ini berarti HRtidak berpengaruh signifikan positif terhadap SGR sebab nilai signifikansi $>\alpha 5 \%$, yaitu0.8545> 5\% serta, t-hitung $<$ t-tabel yaitu, $0.1838<1.9794$ dan koefesien $\beta_{2}$ LRpositif yaitu 0.2628, dengan t-hitung 0.0711, dan signifikan pada $\alpha 5 \%$. Hal ini berarti LR tidak berpengaruh signifikan positif terhadap repaysebab nilai signifikansi $>\alpha 5 \%$, yaitu $0.9434>5 \%$,serta, t-hitung $<$ t-tabel yaitu, $0.0711<1.9794$

Hipotesis ketiga merupakan model persamaan regresi yang digunakan untuk mengestimasi pengaruh pengaruhtinggi tingkat pembayaran utang maka kinerja operasi jangka panjang akan lebih baik disimbolkan dengan $\beta_{1}$ POSTIPO dan $\beta_{2}$ POSTIPO*HR. Berdasarkan Tabel 4.6 diketahui bahwa koefisien $\beta_{1}$ POSTIPO bernilai negatifyaitu -0.0057 , dengan t-hitung 0.0998 , dan signifikan pada $\alpha 5 \%$. Hal ini berarti POSTIPO tidak berpengaruh signifikan positif terhadap OCF_TA sebab nilai signifikansi $>\alpha 5 \%$, yaitu $0.9208>5 \%$ serta, t-hitung $<$ t-tabel yaitu, $-0.0998<2.001$ dan koefesien $\beta_{2}$ POSTIPO*HR negaitif yaitu-0.0369, dengan t-hitung -1.2076 , dan signifikan pada $\alpha 5 \%$. Hal ini berarti POSTIPO*HR tidak berpengaruh signifikan positif terhadap OCF_TA sebab nilai signifikansi $>\alpha 5 \%$, yaitu $0.2319>5 \%$, serta, $t$-hitung $<\mathrm{t}$-tabel yaitu, $-1.2076<2.001$.

\section{HASIL DAN PEMBAHASAN}

Pengaruh semakin tinggi tingkat leverage dan spread bunga maka semakin memotivasi perusahaan menggunakan hasil IPO untuk membayar utang.

Hipotesis pertama pada penelitian ini adalah leverage dan spread bunga berpengaruh positif dan signifikan terhadap motivasi penggunaan dana IPO untuk membayar utang, dimana semakin tinggi leverage dan spread bunga maka akan meningkatkan motivasi perusahaan untuk menggunakan dana IPO untuk membayar utang. Berdasarkan hasil penelitian, diketahui DER berpengaruh signifikan, koefisien DER bernilai positif yaitu 0.5774 , signifikan pada $\alpha 10 \%$. yang berarti DER berpengaruh signifikan positif terhadap repay, sebab nilai signifikansi $<\alpha 10 \%$, yaitu $0.0991<10 \%$ hal ini menunjukkan bahwa tingginya leverage dapat meningkatmotivasi penggunaan dana IPO, dimana semakin tinggi leverage maka akan meningkatkan motivasi penggunaan dana IPO untuk pembayararan utang.

Utang adalah salah satu sumber pendanaan utama yang dilakukan perusahaan dan merupakan akun penting yang mengindikasikan perusahaan dalam kondisi yang baik atau sebaliknya, tingginya tingkat utang dapat menghambat pertumbuhan perusahaan untuk itu perusahaan harus memilih alternatif pendanaan lain untuk dapat memperbaiki keadaan perusahaan. Dalam dunia bisnis yang ketat perusahaan harus memiliki strategi bisnis yang baik dan inovasi baru agar dapat terus bertahan, hal itu dibutuhkan sumber dana yang besar namun, jika perusahaan memiliki tingkat leverage yang tinggi maka laba yang dihasilkan sebagian besar digunakan untuk menutupi kewajiban sehingga mempengaruhi operasional perusahaan. Kondisi 
yang demikian memotivasi perusahaan untuk melakukan IPO sebagai alternatif pendanaan. Hasil ini konsisten dengan penelitian Fan (2018), yang menemukan DER berpengaruh singnifikan terhadap repay. Menurut Fan (2018) perusahaan yang sangat leverage sangat mungkin menggunakan dana IPO untuk membayar utang.

Variabel bebas spread bunga tidak berpengaruh signifikan, koefesien spread bunga negatifyaitu -0.4085 , signifikan pada $\alpha 5 \%$. Hal ini berarti SB tidak berpengaruh signifikan positif terhadap repaysebab nilai signifikansi $>\alpha 5 \%$, yaitu $0.3370>5 \%$. hal ini menunjukkan tingginya spread bunga tidak dapat menjelaskan motivasi perusahaan menggunakan dan IPO untuk membayar utang. Hasil ini konsisten dengan penelitian Amor dan Kooli (2017) yang menemukan bahwa perusahaan cenderung melakukan IPO ketika valuasi pasar tinggi. Penelitian ini tidak sejalan dengan penelitian Fan (2018) yang menemukan pembayaran utang tinggi pasca IPO menurunkan beban bunga. Spread bunga adalah selisih bunga pinjaman perusahaan dengan bunga Bank Indonesia, perusahaan memiliki banyak alternatif pendanaan tidak hanya pinjaman bank tetapi seperti utang terhadap pihak ketiga dan obligasi jadi perusahaan dapat memilih alternatif sesuai dengan resiko yang akan diterima perusahaan. Faktanya pada penelitian ini perusahaan tidak hanya berfokus pada satu alternatif pendanaan namun satu perusahaan memiliki beberapa alternantif pendanaan berbeda dengan penelitian sebelumnya yang dilaksanakan di Jepang. Jepang memiliki sistem tradisional yang alternatif pendanaan berorientasi pada bank fakta ini menunjukan perusahaan swasta jepang sangat mengandalkan pinjaman bank.

Berdasarkan hasil penelitian, maka dapat disimpulkan bahwa tinggi leverage yang diukur dengan rasio utang (DER) dapat meningkatkan memotivasi perusahaan menggunakan dana IPO untuk membayar utang. Terbukti bahwa tingkat leverage yang tinggi dapat menghambat pertumbuhan perusahaan, berbeda dengan spread bunga, tingginya tingkat spread bunga tidak dapat menjelaskan motivasi perusahaan menggunakan dana IPO untuk membayar utang.

\section{Pengaruh semakin tinggi tingkat penggunaan dana IPO untuk pembayaran utang maka semakin tinggi pertumbuhan perusahaan}

Hipotesis kedua pada penelitian ini adalah semakin tinggi tinggkat penggunaan dana IPO untuk membayar utang maka semakin tinggi pertumbuhan perusahaan. Hasil penelitian ini tidak dapat membuktikan bahwa tinggi tinggkat penggunaan dana IPO untuk membayar utang maka semakin tinggi pertumbuhan. Hal ini dapat dilihat dari hasil regresi pada tabel 4.8 diketahui bahwa koefisien HR bernilai positif yaitu 0.6820 , dengan nilai signifikan pada $\alpha 5 \%$. Hal ini berarti HR tidak berpengaruh signifikan positif terhadap SGR sebab nilai signifikansi yaitu0.8545> 5\%. Penelitian ini tidak dapat membuktikan tingginya tingkat pembayaran utang dapat meningkatkan pertumbuhan penjualan perusahaan. Variabel bebas LR juga tidak berpengaruh signifikan positif terhadap SGR sebab nilai signifikansi $>\alpha 5 \%$, yaitu $0.9434>5 \%$, membuktikan rendahnya tingkat pembayaran utang tidak menjelaskan peningkatan pertumbuhan penjualan.

Hasil penelitian ini berbeda dengan penelitian Fan (2018) yang menyimpulkan bahwa pembayaran utang lebih tinggi menunjukkan pertumbuhan penjualan lebih tinggi dari pada pembayaran utang rendah. Banyak hal yang dapat mempengaruhi pertumbuhan perusahaan, Fan (2018), menyatakan bahwa peningkatan pertumbuhan perusahaan tidak hanya didorong oleh pembayaran utang pasca IPO namun diakibatkan olehjumlah dana IPO yang besar. Beberapa faktor lain yang dapat menyebabkan hipotesis ini tidak berpengaruh signifikan. Pertama karena tahun pengamatan yang hanya mengunakan satau tahun sesudah IPO, hal ini menyebabkan hasil 
penelitian ditolak karena pertumbuhan perusahaan tidak dapat dilihat dari jangka waktu yang pendek. Kedua sampel yang digunakan tidak fokus pada sektor tertentu dan ketiga pada penelitian ini sampel yang digunakan hanya 64 perusahaan berbeda dengan penelitian sebelumnya yang memiliki sampel 1424 perusahaan.

\section{Semakin tinggi tingkat pembayaran utang maka kinerja operasi jangka panjang akan lebih baik}

Hipotesis ketiga pada penelitian ini adalah Semakin tinggi tingkat pembayaran utang maka Kinerja operasi jangka panjang lebih baik diwakili oleh operating cash flow to total asset (OCF_TA). Hasil penelitian ini tidak dapat membuktikan bahwa tinggi tinggkat penggunaan dana IPO untuk membayar utang maka kinerja operasi perusahaan semakin baik. Hal ini dapat dilihat dari hasil regresi linear berganda pada tabel 4.6, diketahui bahwakoefisien POSTIPO bernilai negatifyaitu -0.0057 , dengan signifikan pada $\alpha<5 \%$. Hal ini berarti POSTIPO tidak berpengaruh signifikan positif terhadap OCF_TA sebab nilai signifikansi $>\alpha 5 \%$, yaitu $0.9208>$ $5 \%$ dan koefesien $\beta_{2}$ POSTIPO*HR negaitif yaitu-0.0369hal ini berarti POSTIPO*HR tidak berpengaruh signifikan positif terhadap OCF_TA sebab nilai signifikansi $>\alpha 5 \%$, yaitu 0.2319> $5 \%$. penelitian ini membuktikan bahwa keadaan setelah pasca IPO dan interaksi tingginya pembayaran utang pasca IPO tidak dapat menjelaskan kinerja operasi jangka panjang yang lebih baik.

Berbeda dengan penelitian Fan (2018) yang menyimpulkan bahwa Semakin tinggi tingkat pembayaran utang maka Kinerja operasi jangka panjang lebih baik. Hasil penelitian ini sesuai dengan penelitian Amor dan Kooli (2017) yang menunjukkan perusahaan yang saat IPO membayar utang atau menggunakan hasil IPO untuk membayar utang digambarkan memiliki kinerja yang paling rendah. Menurut penelitian Amor dan Kooli (2017) perusahaan yang membayar utang pada pasca IPO memiliki kinerja perusahaan yang buruk dimasa depan karena dana yang diperoleh tidak digunakan pada kegitan operasional perusahaan secara langsung.

Menurut Amor dan Kooli (2017) perusahaan memungkinkan berinvestasi dalam proyekproyek yang besar namun harus dilepaskan jika perusahaan tidak go public, jadi banyak hal yang mempengaruhi perusahaan untuk IPO selain untuk meningkat kinerja operasi jangka panjang lebih baik. Beberapa faktor lain yang menyebabkan hipotesis ini tidak berpengaruh signifikan yang pertama karena tahun pengamatan yang hanya mengunakan satau tahun pasca IPO, hal ini menyebabkan hasil penelitian ditolak karena kinerja operasi perusahaan tidak dapat dilihat dari jangka waktu yang pendek. Kedua sampel yang digunakan tidak fokus pada sektor tertentu dan ketiga pada penelitian ini sampel yang digunakan hanya 64 perusahaan berbeda dengan penelitian sebelumnya yang memiliki sampel 1424 perusahaan.

\section{SIMPULAN, KETERBATASAN DAN SARAN Kesimpulan dan Implikasi}

Penelitian ini bertujuan untuk melihat seberapa besar pengaruh pembayaran utang pasca IPO terhadap pertumbuhan perusahaan tahun 2013-2017 pada perusahaan yang terdaftar di BEI. Berdasarkan hasil temuan penelitian dan pengujian hipotesis yang diajukan sebelumnya dapat disimpulkan bahwa:Hipotesis pertama dengan variabel bebas DER berpengaruh singnifikan dan dapat membuktikan tingginya leverage meningkatkan motivasi perusahaan menggunakan IPO untuk membayar utang. Sedangkan Spread bunga tidak berpengaruh singnifikan yang artinya 
tinggi tingkat spread bunga tidak dapat menjelaska motivasi perusahaan menggunakan dana IPO untuk membayar utang.

Hipotesis kedua variabel high retiring tidak berpengaruh singfikan terhadap pertumbuhan penjualan yang artinyatinggi tinggkat penggunaan dana IPO untuk membayar utang tidak terbukti meningkatkan pertumbuhan penjualan dan variabel low retiring tidak berpengaruh singnifikan terhadap pertumbuhan penjualan yang artinya tinggi tinggkat penggunaan dana IPO untuk membayar utang tidak menjelaskan peningkatan pertumbuhan penjualan. Hipotesis ketiga, variabel POSTIPO tidak berpengaruh singnikan terhadap kinerja operasi yang berarti keadaan pasca IPO tidak dapat membuktikan tinggi tingkat pembayaran dapat membuat Kinerja operasi jangka panjang perusahaan lebih baik dan variabel POSTIPO*HIGH RETIRING tidak berpengaruh singnifikan terhadap kinerja operasi yang artinya reaksi keadaan pasca IPO dengan tingginya tingkat pembayaran utang tidak dapat membuktikan kinerja operasi jangka panjang lebih baik.

Implikasi pada penelitian ini bahwa perusahaan yang memiliki leverage yang tinggi terbukti dapat meningktakan motivasi perusahaan menggunakan dana IPO untuk membayar utang namun, berbeda denga spread bunga tidak dapat menjelaskan motivasi perusahaan menggunakan dana IPO untuk membayaran utang. Tinggi tingkat pengembalian (High Retiring) tidak terbukti meningkatkan pertumbuhan perusahaan. Tinggi tingkat pembayaran utang tidak terbukti meningkatkan kinerja operasi jangka panjang lebih baik.

\section{Keterbatasan}

Peneliti telah berusaha merancang dan mengembangkan penelitian sedemikian rupa, namun masih terdapat beberapa keterbatasan dalam penelitian ini yang masih perlu diperbaiki bagi peneliti selanjutnya, yaitu antara lain:

1. Penelitian ini baru menggambarkan potret pada semua sektor perusahaan terkecuali sektor keuangan tidak fokus pada satu sektor sehingga data penelitian tidak dapat menggabarkan industri yang mana lebih cenderung menggunakan dana IPO untuk membayar utang sehingga dapat dibandingkan

2. Tahun pengamatan yang digunakan dalam pengambilan sampel hanya mencakup pasca IPO pada hipotesis satu, satu tahun sesudah pasca ipo pada hipotesis kedua dan satu tahun pasca IPO pada hipotesi ketiga. Hal ini dikarenakan keterbatasan informasi dan keterbatasan data yang tidak lengkap.

3. Sampel yang digunakan hanya 64 sampel dikarenakan banyak perusahaan tidak menyajikan informasi yang akurat pada laporan keuangan.

4. Variabel yang digunakan banyak yang menggunakan dummy dengan sampel yang sedikit sehingga hasil penelitian ini rata-rata tidak sesuai dengan prediksi.

\section{Saran}

Berdasarkan kesimpulan dan keterbatasan penelitian yang telah diuraikan sebelumnya, maka saran yang dapat peneliti berikan, yaitu:

1. Bagi peneliti selanjutnya diharapkan dapat menggunakan sektor tertentu hingga dapat melihat kecenderungan setiap sektor yang berbeda

2. Bagi peneliti selanjutnya diharapkan dapat menambah tahun pengamatan dengan meneliti lebih dari 4 tahun agar hasil yang diperoleh lebih berkualitas. 
3. Bagi peneliti selanjutnya dapat menambahkan data yang terkait pertumbuhan perusahaan dan menggunakan sampel yang memiliki utang di bank

4. Bagi peneliti selanjutnya yang tertarik untuk meneliti judul yang sama, sebaiknya mempertimbangkan dan mencari variabel independen lainnya yang berhubungan dengan pertumbuhan perusahaan.

\section{DAFTAR PUSTAKA}

Ahmad, R. dan Ali, H. (2010). Manajemen Keuangan. Jakarta : Mitra Wacana Media

Ahn, S., Denis, D.J. dan Denis, D.K. (2006). Leverage and investment in diversified firms. Journal of Financial Economics, 79, 317-337.

Almilia, L. S. (2003). Analisis Faktor-Faktor yang Mempengaruhi Status Perusahaan Pasca IPO dengan Mengunakan Tehnik Analisis Multinominal Logit. Jurnal ekonomi dan bisnis, Vol 18, No. 4.

Amor, S.B. dan Kooli, M. (2017). Intended use of proceeds and post-IPO performance. Quarterly Review of Economics and Finance, 65, 168-181.

Apriliani, T. dan Hikmah. (2006). Reputasi Penjaminan Emisi, Reputasi Auditor, Persentase Penjamin Emisi, Ukuran Perusahaan yang Melakukan Kebijakan Initial Public Offering (IPO) di Indonesia. Syimposium Nasional Akuntansi X.

Atmaja, L. S. (2013). Manajemen Keuangan Edisi Revisi. Yogyakarta: ANDI

Brau, J.C., Couch, R.B. dan Sutton, N.K. (2012). The desire to acquire and IPO long-run underperformance. Journal of Financial and Quantitative Analysis, 47, 493-510.

Brigham dan Houston. (2006). Fundamental Of Financial Management dasar dasar keuangan manajemen. Jakarta: Salemba Empat

Busaba, W.Y., Benveniste, L.M. dan Guo, R.-J. (2001). The option to withdraw IPOs during the premarket: empirical analysis. Journal of Financial Economics 60, 73-102.

Busaba, W.Y., Benveniste, L.M., dan Guo, R.-J. (2001). The option to withdraw IPOs during the premarket: empirical analysis. Journal of Financial Economics, 60, 73-102.

Fahmi, I. (2011). Analisis Laporan Keuangan. Lampulo: Alfabeta

Fama, E. F. dan French, K. R. (1998). Taxes, Financing Decisions, and Firm Value. The Journal of Finance, 53(3)

Fan, P. (2018). Debt retirement at IPO and firm growth. Jurnal Ekonomi dan Bisnis.JEB 5822

Febriani, L. (2013). Pengaruh Likuiditas, Leverage dana Profitabilitas terhadap Initial Return pada Perusahaan yang Melakukan Initial Public Offering. Jurnal Ekonomi dan Bisnis.

Firnanti, F. (2011). Faktor-faktor yang mempengaruhi struktur modal perusahaan manufakturdi Bursa Efek Indonesia. Jurnal bisnis dan Akuntansi, 13 (2), 119-128

Hanafi, M. M. (2004). Manajemen Keuangan. Yogyakarta: BPFE

Harsono, M. (2002). Prosedur Pengujian Variabel Kontrol dan Moderator dalam Penelitian Perilaku dengan Mengunakan SPSS 10.00. Seminar Manajemen, Fakultas Ekonomi, Universitas Sebelas Maret.

Hart, O. Dan Moore, J. (1995). Debt and Seniority: An Analysis of the Role of Hard Claims in Constraining Management. American Economic Review, 567-585.

Heizer dan Render. (2015). Manajemen Operasi Manajemen Keberlangsungan dan Rantai Pasokan. Edisi Kesebelas. Jakarta: Selemba Empat.

Jogiyanto, H. (2002). Teori Portofolio dan Analisis Investasi. Edisi ketiga. Yogyakarta. BPFE. 
Joni dan Lina. (2010). Faktor-Faktor yang Mempengaruhi Struktur Modal. Jurnal bisnis dan akuntansi, 12(2), 81-96.

Kasmir. (2010). Pengantar Manajemen Keuangan. Jakarta: Penamedia Group.

Keown dkk. (2008). Manajemen Keuangan: Prinsip dan Penerapan. Indonesia: PT Macana Jaya Cemerlang.

Kusnadi dkk. (2000). Akuntansi Keuangan Menengah (Intermediate) (Prinsip, Prosedur, dan Metode). Malang: Universitas Brawijaya.

Levis, M. (2011). The performance of private equity-backed IPOs. Financial Management, 40, 253-277.

Lowry, M. (2003). Why does IPO volume fluctuate so much?. Journal of Financial conomics, 67, 3-40.

Machfoedz, M. (2007). Pengantar Bisnis Modern. Yogyakarta: C.V Andi Offset.

Martalena dan Malinda. (2011). Pengantar Pasar Modal. Yogyakarta: ANDI

Martono dan Harjito, D. A. (2010). Manajemen Keuangan. Yogyakarta: Ekonisia

Mulyono, B. (2009). Pengaruh Debt to Equity Ratio, Insider Ownership, Size, dan Investment Opportunity Set terhadap kebijakan Deviden. Jurnal Bisnis Strategi, 32(1)

Myers, S.C. (1977). Determinants of corporate borrowing. Journal of Financial Economics, 5, 147-175.

Natali, O. (2013). Leverage pengaruhnya terhadap nilai perusahaan pada industri manufaktur yang Go Public di Indonesia. Jurnal EMBA, 1(3).

Pagano, M., Panetta, F. Dan Zingales, L. (1998). Why do companies go public? An empirical analysis. Journal of Finance, 53, 27-64.

Pradana, H. R. (2013). Pengaruh Risiko Bisnis, Struktur Asset, Ukuran dan Pertumbuhan Penjualan terhadap Struktur Modal. Accounting Analysis Journal, 2(4)

Riyanto, B. (2010). Dasar-Dasar Pembelanjaan Perusahaan. Yogyakarta: Yayasan Badan Penerbit Gadjah Mada

Subramanyam, K. R., dkk. (2005). Analisis Laporan Keuangan. Jilid Dua. Jakarta: Salemba empat.

Sujoko dan Soebiantoro, U. (2007). Pengaruh Struktur Kepemilikan, Leverage, Faktor Intern, Dan Faktor Ekstern terhadap Nilai Perusahaan (Studi Empirik Pada Perusahaan manufaktur dan non manufaktur di Bursa Efek Jakarta), Jurnal Manajemen dan Kewirausahaan, 9(1)

Sulindawati, dkk. (2017). Manajemen keuangan sebagai dasasr pengambilan keputusan bisnis. Depok: Rajawali pers

Suliyanto. (2011). Ekonometrika Terapan: Teori dan Aplikasi dengan SPSS. Yogyakarta: ANDI.

Suwardjono. (2005). Teori Akuntansi Perekayasaan Pelaporan Keuangan. Edisi Ketiga. Yogyakarta. BPFE

Syamsuddin, L. (2009). Manajemen Keuangan Perusahaan. Jakarta: Raja Grafindo Persada

Takahashi, H. dan Yamada, K. (2015). IPOs, Growth, and the impact of relaxing listing requirements. Jurnal of Banking \& Finance, 59, 505-519. 